\title{
The Resposibility for the Faithfulness of the Accounting Statements of Enterprises
}

Ivashkevich V.B. ${ }^{a}$

\section{Spiryagina N.S.b}

a b Kazan Federal University, Institute of Management, Economics and Finance, Kazan, 420008, Russia

Email: sns@yandex.ru

\section{Doi:10.5901/mjss.2015.v6n1s3p357}

\section{Abstract}

The article discusses the criteria of the faithfulness of financial reporting, defines the content and the degree of the accountant and auditor's responsibility for the faithfulness of its indicators. The given measures are recommended to strengthen responsibility for the quality of accounting and reporting in commercial organizations. The article also defines the main subjects who bear financial losses by using data of unfaithful financial reporting of commercial organizations and the basic problems in assessing responsibility for the faithfulness of the statements.

Keywords: veiling, faithfulness, misrepresentation, fraud, responsibility, accountability

\section{Introduction}

The faithfulness of the financial (accounting) statements has always been an obligatory condition of its preparation and presentation [1]. No matter how successful or unsatisfactory the results of the company, its financial statements must be faithful, and the truth, as it is known, should not depend on those whom it seeks to serve [3]. However, in real life the principle of faithfulness often is not observed due to various reasons, including the cases when the management of the organization and sometimes its owners are interested in the distortion of the balance sheet and other forms of reporting [11]. Usually it happens when a general manager of an unprofitable company with a difficult financial position does not want to admit the mistakes made by an inappropriate economic management, especially if competitors have been more successful. It is tempted to retouch balance sheet and other forms of reporting, using some well-known accountant techniques ("to shade", as the accountant Platon Zibkin said in "The truth is good but happiness is better" A.N. Ostrovsky's play). Immediately the head is not worse than others, and the company is ready to be given a credit and it is ready to be provided with everything it needs without an advance payment. The wish to embellish the accounting statements is large enough, the point is to implement it skillfully. Sometimes it happens that very good results of the company are consciously underestimated to pay less taxes and dividends to the owners. And in that and in other case, the financial statements do not reveal the truth. The desire to counteract the deliberate and unintentional veiling of accounting and reporting led to the birth of the audit profession [2].

\section{Theory}

Particularly acute problem of faithfulness of accounting and quality of the audit reporting occur in conditions of instability of the financial system of the state and its economic subjects. Being in the inevitable financial difficulties, enterprises are looking for a way out of this situation, including attracting Bank loans and other borrowed funds, external investment, Bank guarantees etc [10]. Financial market Institutions that make decisions about participation in such operations based on the uncertain faithfulness of financial reporting of clients, threatened to lose its own liquidity and take additional financial losses.

There are a number of related issues to solve the problems of responsibility for the quality of accounting and reporting of the enterprises:

- what the faithfulness of financial reporting is, how it is characterized, what amount of errors could be allowed to consider it trust worthy;

- who is responsible for the faithfulness of the indicators and other information contained in the financial statements: the accountant, the auditor or if both, in what degree each of them; 
- what measures should be taken to individuals and entities in cases of intentional distortion of the financial statements, resulting in investor or creditor's losses and who and how should be punished for it [9].

The answer to the first question is not as simple as it seems to be as the criteria for accounting assessment and the objectivity of the audit report on the financial statements of the company are fairly conventional and are of a general, largely abstract, nature [12]. According to international standards (IFRS) reporting is considered to be faithful, if the presentation and disclosure of information allows the user of the reporting data to draw conclusions about the company's financial position, financial results of its operations and changes in financial position and to take economic decisions based on these finding [14]. In audit report on the financial statements the auditor expresses the opinion on the statements compliance in all material respects according to the adopted rules of accounting and financial reporting. Accounting of Russian enterprises is believed to be faithful not on the reality reflection, the actual condition of the assets, liabilities, expenses and results of operations, but on the compliance of the rules by the accountant: applicable legislation, primarily the Federal law "On accounting", the Chart of Accounts, instructions for its use, the latest edition of the accounting standards in the Russian Federation and other regulations and rules. Many of them admit the possibility of ambiguous interpretation and application in the accounting policies of the organization, which will undoubtedly affect the financial statements. Additionally, the financial statements may be examined for compliance not only with national requirements but international standards (IFRS) or US GAAP with other criteria for the assessing of the data objectivity [8].

In the audit the distortion between the faithfulness and bias of indicators of the financial statements is called as the materiality, which the auditor determines by himself [7]. At the same time it is said that the auditor's report cannot and should not be interpreted by the client and the user of the financial statements as an assurance that other circumstances which affect or are likely to affect the financial statements do not exist [2]. As the accountant for the company, Russian auditor believes the financial statements are trust worthy if they are, in all material respects comply with the accepted rules of accounting and financial reporting at the time of inspection.

Faithfulness, in our opinion, should be taken literally as truth, loyalty and dignity of those who prepared and checked financial statements, their professional judgment, for which they must take the moral, professional, and, if necessary other responsibility [5].

Responsibility for the quality of the client's financial statement audit is clearly imposed on the head of the audit firm, even though the Auditor's Report is signed by the Director of the auditing firm. A professional accountant working for the enterprise is placed in a more complicated situation. Responsibility for violation of accounting rules, and the unfaithfulness of reporting is established by the current legislation in article 156.11 of the code of administrative offences, article 120 of the Tax code and article 159.1 of the Criminal code of the Russian Federation. In them the main responsibility lies on the perpetrator of distortion, mostly on the heads of the organizations whose initiative was veiling of reporting information, but at the same time on the head of account services - the chief accountant, who made it technically or methodologically. When Law \# 402-FZ "On accounting" was approved almost nothing has changed in respect of the responsibility of the chief accountant: he is still responsible for the formation and implementation of accounting policies and methodologically correct accounting, timely submission of complete and faithful financial statements [1]. The head of the organization is solely responsible for the data reflected in the accounting registers and associated faithfulness of reporting only in cases of a dispute regarding the accounting between the head of the economic entity and the chief accountant, when he is acting on the written instructions of organization's head. The head of the company is a person, who gives orders which the chief accountant of the company obeys even his opinion is different and this is invariably written in the Law \# 402-FZ. It means that the chief accountant should obey only the head of the organization, and not its Finance Director and other deputies, as it sometimes occurs in practice.

Concerning the responsibility of the Director of the company for the faithfulness of financial reporting in the Federal law \# 402-FZ "On accounting" (c.8, Article 7) reads: "In the event of a dispute in respect to accounting between the head of the economic entity and the chief accountant or other officer charged with the maintenance of accounting records, or a person with whom the contract on rendering services on accounting is concluded:

1) the data contained in the primary accounting document, accepted (not accepted) by chief accountant or other officer charged with the maintenance of accounting records, or a person with whom the contract on rendering services in accounting is concluded, to register and accumulate in the accounting documents by written order of the head of the economic entity, which is solely responsible for the resulting information;

2) the object of accounting is reflected (not reflected) by the chief accountant or other officer charged with the maintenance of accounting records, or a person with whom the contract on rendering services in accounting is concluded, in the accounting (financial) statements on the basis of a written order of the head of the economic entity, which is solely responsible for the faithfulness of presentation of the financial position of an economic 
entity at the reporting date, the financial results of its activity and cash flow for the reporting period" [1].

As practice shows, the written orders to the chief accountant that are contrary to applicable law, the head of the economic entity, as a rule, does not give, but asks with varying degree of explicitness to find a way how to do this or that desirable, but not quite legitimate operation, or report required information for company, without violating the rules of accounting. This is the most difficult part of the relationship between the head of the organization and chief accountant [13]. Usually in such cases, it proceeds as follows:

a) orders and proposals of the same kind are considered seriously if they come directly from the General Director of the company. Other leaders must agree upon their recommendations with the Director and get his support;

b) evaluate questionable from the standpoint of the laws and accounting rules, recommendations and directives from the point of view of possible consequences of their execution. If direct or indirect material interest of specific individuals or groups is viewed such proposals should be rejected;

c) if the proposals are aimed at the general interests of the collective workers and owners of the organization, the improving the enterprise's financial position:

- $\quad$ it is necessary to exclude the possibility of tax evasion or illegal reduce of them, but to offer other legal methods of tax optimization, recommend the Director what must be done in advance;

- instructions on changing the order and form of execution of the previously executed or prolonged economic agreements, sanctions, changes of the priority of payments, on the promotion and punishment of individual workers and groups of units, etc. should be supported, but be warned about the possibility of negative consequences of such decisions, especially if they are likely to be.

Disagreements between the head of the organization and the chief accountant shall be generally resolved within the enterprise through mutual understanding and compromise of opinions. According to the international standards the compromise cannot be, if the head of the organization:

- violates the requirements of current legislation;

- forces a professional accountant to disturbance, staying away;

- $\quad$ lies or misleads in cases where he must tell the truth;

- officially reports information, distorting the facts.

The question of the punishment forms of physical and legal persons who are guilty of financial reporting unfaithfulness, and caused with these additional costs and losses to qualified users, including the banking system and financial markets, until recently is not definitely solved. It is considered that in an extreme distortion and obfuscation of these financial statements of economic subjects is one of the forms and methods of fraud, that is, a crime in the sphere of economy, which is the theft of another's property or the acquisition of another's property by deception or abuse of trust. Proven fraud using false financial statements is prosecuted on the basis of a judicial decision [6].

\section{Conclusions}

In general, the position of the financial statements faithfulness of some Russian companies that are clients of financial markets cannot be considered satisfactory. The first suffer is a banking system, where the amount of arrears and defaulted loans by the clients, including due to the complete trust in these financial statements, annually increase. Credit organizations, investment funds and financial institutions, rather than relying only on data of a balance sheet and other reporting forms, are forced to resort to special studies of credit status and reliability of the companies with whom they are dealing, or intend to deal with, attracting additional sources of information, including their owns. Meanwhile, the possibilities of using the data of financial statements of the organizations-clients, auditors who validate them, legislative and executive bodies are not exhausted in the fight against fraud [4]. At the same time it is necessary to improve the reporting, the method of forming its performance and to do the best to make it reflect the reality [15].

\section{References}

Federal law "On accounting" \# 402-FZ dd 06 December 2011.

Federal law "On auditing" \# 307-FZ dd 30 December 2008.

Aktaş, R., Karğin, M. Timeliness of reporting and the quality of financial information // International Research Journal of Finance and Economics. Volume 63, March 2011, pp. 71-77.

Beutler, I.F. What makes wealth grow? A wealth sensitive financial statement analysis // Journal of Financial Counseling and Planning. Volume 25, Issue 1, 2014, pp. 90-104.

Fifka, M.S., Pobizhan, M. An institutional approach to corporate social responsibility in Russia // Journal of Cleaner Production. Volume 
82, 1 November 2014, pp. 192-201.

Filip, A., Labelle, R., Rousseau, S. Legal regime and financial reporting quality // Contemporary Accounting Research. 2014.

Griffin, J.B. The Effects of Uncertainty and Disclosure on Auditors' Fair Value Materiality Decisions // Journal of Accounting Research. 2014.

Kaspina, R.G., Shneydman, L.Z. New approach to the oil companies' corporate reporting // Neftyanoe Khozyaistvo - Oil Industry, 9 , 2013, pp. 14-17.

Li, Y.-J., Li, R. Research on financial statements system based on enterprise resource // Proceedings of 2013 4th International Asia Conference on Industrial Engineering and Management Innovation, IEMI 2013, 2014, pp. 389-399.

Sarkin, A.V., Bagautdinova, N.G., Averianov, B.A. Formulation of development strategies of machinery building complex enterprises and estimation of their implementation efficiency // World Applied Sciences Journal, 27(13), 2013, 170-173.

Klychova G.S., Faskhutdinova M.S., Sadrieva E.R. Budget efficiency for cost control purposes in management accounting system // Mediterranean Journal of Social Sciences vol. 5 № 24, November 2014, pp. 79-83

Markaryan, S.E., Snetkova, T. A., Khairullina, D. V. Administrative aspects of accounting organization. Russian experience and problems // Life Science Journal, 11(8), 2014, pp. 107-111.

Needles Jr., B.E., Shigaev, A., Powers, M., Frigo, M. L. Strategy and integrated financial ratio performance measures: A longitudinal multi-country study of high performance companies // Studies in Managerial and Financial Accounting, 20, 2010, pp. 211-252.

Needles Jr., B.E., Shigaev, A., Powers, M., Frigo, M. L. Operating characteristics of high performance companies: Strategic direction for management // Studies in Managerial and Financial Accounting, 28, 2014, pp. 25-51.

Bagautdinova N.G., Hadiullina G.N., Sarkin A.V., Pratchenko O.V. Typology of the regions with the account of level of influence of infrastructure facilities on the structure of economic areas // Asian Social Science, Volume 10, 28 2014, Pages 57-61. 